Anna Maria Wajda ${ }^{1}$

Uniwersytet Papieski Jana Pawła II w Krakowie

\title{
Obrazy ze świata przyrody w nauczaniu Jezusa o ubóstwie i bogactwie
}

Lektura czterech ewangelii ukazuje specyficzną formę nauczania Jezusa. Przejawia się ona zasadniczo w tym, że nie ma ono charakteru dyskursu o charakterze filozoficznym, bazującego na precyzyjnie dobranych pojęciach, tylko tworzywem dla głoszonych przez Mistrza z Nazaretu nauk jest zasadniczo otaczający Go świat. W rezultacie niejednokrotnie snuje On swe rozważania religijno-moralne, przywołując obrazy z życia mieszkańców Galilei czy Judei (rolników, rybaków, pasterzy, robotników najemnych), nawiązuje w nich do znajomości miejscowej fauny i flory oraz odwołuje się do zjawisk naturalnych, wspominając na przykład o niebie, które charakterystycznie czerwienieje przy zachodzie lub wchodzie słońca (por. Mt 16, 2-3). Co więcej zauważyć można, że dla nauczania Jezusa nie są znamienne długie i zawiłe wywody, ale tzw. apo-

$1 \quad$ Anna Maria Wajda - dr inż. nauk rolniczych w zakresie sztuki ogrodowej i dr nauk teologicznych w zakresie teologii biblijnej. Wykładowca WSD OFMCap w Krakowie oraz UPJPII w Krakowie. Zajmuje się zagadnieniami związanymi z przyrodą w Biblii, zwłaszcza fauną i florą biblijną, a także życiem codziennym w czasach biblijnych. Jest członkiem zwyczajnym Stowarzyszenia Biblistów Polskich, Sekcji Biblijnej Polskiego Towarzystwa Teologicznego oraz członkiem Rady Naukowej zeszytu „Nauki Przyrodnicze - Rocznik Przemyski”, wydawanego przez Towarzystwo Przyjaciół Nauk im. Kazimierza Marii Osińskiego w Przemyślu. E-mail: wajdaannamaria@gmail.com. 
ftegmaty lub logiony². Dzięki swej krótkiej i bogatej w treść formie były one łatwe do zapamiętania, a to z kolei przekładało się na popularność tego typu wypowiedzi na starożytnym Bliskim Wschodzie, który słynął z kultury oralnej i związanych z nią technik mnemotechnicznych.

W związku z powyższym nie należy być zaskoczonym faktem, że w Jezusowym nauczaniu o ubóstwie i bogactwie także pojawiają się tego typu formy wypowiedzi, charakteryzujące się równocześnie mocnym osadzeniem w realiach przyrodniczych i życiu codziennym ówczesnych mieszkańców Palestyny. Będą one przedmiotem niniejszego opracowania, którego celem jest to, aby poprzez pochylenie się nad występującymi w nich odniesieniami do świata fauny i flory uwypuklić specyfikę analizowanych wypowiedzi Nauczyciela z Nazaretu, ale także pokazać, że współpraca egzegety z zoologiem i botanikiem może prowadzić do ciekawych spostrzeżeń na gruncie interpretacji tekstu biblijnego.

\section{Jezus uboższy od lisów i ptaków}

Można wyróżnić szereg nowotestamentowych tekstów, które podejmują kwestię ubóstwa Chrystusa. Jednym z nich są chociażby następujące słowa św. Pawła: „Znacie przecież łaskę Pana naszego Jezusa Chrystusa, który będąc bogaty, dla was stał się ubogim, aby was ubóstwem swoim ubogacić" (2 Kor 8, 9; por. także Flp 2, 6-7)33. Odnoszą się one do tajemnicy Boga, który dla naszego zbawienia zupełnie ogołocił się w akcie wcielenia z boskiej kondycji i stał się człowiekiem całkowicie zanurzonym

\footnotetext{
Apoftegmat (gr. apophtegma - maksyma lub sentencja zawierająca normę postępowania) - w Nowym Testamencie terminem tym oznacza się krótkie, lapidarne powiedzenia Jezusa, zawarte w kontekście narracyjnym (np. Mt 8, 20). Występuje najczęściej jako odpowiedź na pytania uczniów w tzw. dyskusjach szkolnych (Mt 19,1-15) lub jako replika na zarzuty nieprzyjaciół w tzw. kontrowersjach (Mk 2,15-17) oraz jako apoftegmat biograficzny (Mt 4, 18-22; Łk 7, 1-10). Logion, 1. mn. logia (gr. wyrocznia) - w Nowym Testamencie oznacza słowo (np. Boga lub Chrystusa); w biblistyce mianem tym określa się krótką, izolowaną wypowiedź Jezusa - za: J. Kudasiewicz, Jezus historii a Chrystus wiary, Lublin 1987, s. 142-143.

Wszystkie cytaty biblijne podano za:Pismo Święte Starego i Nowego Testamentu w przekładzie z języków oryginalnych, opracował zespół biblistów polskich z inicjatywy Benedyktynów Tynieckich (Biblia Tysiąclecia), Poznań $2000^{5}$.
} 
w ludzkim ubóstwie. Jest On bowiem Nowonarodzonym, który zostaje położony w żłobie, a nie w kołysce (por. Łk 2, 7-16). Dorasta w Nazarecie, w biednej i pogardzanej w owym czasie mieścinie, a potwierdzeniem tej niepochlebnej i niewątpliwie popularnej wtedy opinii o tej miejscowości są słowa Natanaela: „Czy może być co dobrego z Nazaretu?” (por. J 1, 46). Co więcej zaangażowanie się Jezusa w przepowiadanie dobrej nowiny o królestwie Bożym zmusza Go do jeszcze większego ogołocenia się, co sam wyraża w słowach: „Lisy mają nory i ptaki powietrzne - gniazda, lecz Syn Człowieczy nie ma miejsca, gdzie by głowę mógł oprzeć” (Mt 8, 20; por. Łk 9,58). Jednakże całkowitym i dobrowolnym upadkiem Bogaczłowieka w ludzkie ubóstwo, osamotnienie, a nawet wykluczenie jest Jego proces, skazanie, i przede wszystkim stracenie na krzyżu.

Powróćmy jednak do przywołanego wyżej apoftegmatu (Mt 8, 20; por. Łk 9,58), który doskonale pokazuje, jak mocno niektóre obrazy ze świata przyrody mogą przemawiać do intelektu słuchaczy. Jednak aby w pełni zrozumieć analizowaną wypowiedź Jezusa, należy nie tylko rozpatrywać ją w kontekście, w jakim zostaje ona użyta, ale także zastanowić się nad charakterem przywołanych w niej obrazów ze świata fauny. Należy przede wszystkim spróbować znaleźć wyjaśnienie, dlaczego jest tu akurat mowa o ptakach i lisach, a nie o innych zwierzętach. Niewątpliwie pomocne w tym będzie uwzględnienie innych biblijnych wzmianek na temat wymienionych tu przedstawicieli świata przyrody. W konsekwencji może to bowiem okazać się cennym przyczynkiem na płaszczyźnie egzegezy niniejszej wypowiedzi Jezusa.

Szerszy kontekst, w jakim analizowany fragment jest przywoływany przez Ewangelistów, pokazuje nam, że Mistrz z Nazaretu doświadcza na tym etapie swego życia osamotnienia, odrzucenia ze strony najbliższych, niezrozumienia, a nawet zostaje bezdomnym. Na taką interpretację pozwala między innymi miejsce tego apoftegmatu w Ewangelii według św. Łukasza $(9,58)$. Umieszczono go bowiem po perykopie, z której dowiadujemy się, iż Jezus wyrusza w swą ostatnią podróż do Jerozolimy (Łk 9, 51), co zarazem oznacza, że na zawsze opuszcza On swą małą ojczyznę - Galileę. Więcej, padają one też po tym, jak z powodu swej nauki został On wyrzucony przez swych rodaków z Nazaretu (por. Łk 4, 29) miasta Jego dzieciństwa i młodości. Nie chcą Go także obcy, bo na począt- 
ku swej drogi do Jerozolimy spotyka się z odrzuceniem przez Samarytan (Łk 9, 52-53). W związku z tym Jezus słusznie zauważa, że w porównaniu ze swoistym ubóstwem, jakiego doświadcza, nawet ptaki i lisy są bogatsze, bo nie są bezdomne i mają swe gniazda i nory ${ }^{4}$. Antoni Paciorek podkreśla jednak, że wypowiedź ta ma swoiste nacechowanie hiperboliczne, gdyż w czasie swej galilejskiej działalności Jezus często zatrzymywał się w Kafarnaum (por. Mt 4, 13-16) ${ }^{5}$, które nawet przyjęło nazywać się Jego miastem (por. Mt 9, 1) .

Zastanówmy się teraz, dlaczego Jezus przywołuje w swej wypowiedzi akurat lisa? Warto także zadać sobie pytanie, czy Mistrz z Nazaretu może odwoływać się do konkretnego gatunku tego zwierzęcia?

Współcześnie, ale było tak również w starożytności (por. bajki Ezopa), lis jest powszechnie kojarzony z chytrością, przebiegłością i zgubnym dla jego ofiar sprytem ${ }^{7}$. Polujący lis rozgląda się, czatuje i wyczekuje odpowiedniej chwili do rzucenia się na zdobycz, zaś podczas samego ataku odznacza się zaskakująca zręcznością. Jezus, odnosząc się do Heroda Antypasa, niewątpliwie przywołuje to zwierzę w znaczeniu symbolu chytrości i przebiegłości: „Idźcie i powiedzcie temu lisowi” (por. Łk 13, 32a) ${ }^{8}$. Podkreślić jednak trzeba, że wzmianka o lisach w analizowanym apoftegmacie (Mt 8, 20; por. Łk 9, 58) nie ma takiego nacechowania. Wyraża raczej spostrzeżenie - mówiąc zaś językiem współczesnej zoologii - obserwację przyrodniczą, odnoszącą się do sposobu bytowania tego zwierzęcia $\mathrm{w}$ jego naturalnym środowisku. Charakterystyczną rzeczą jest bowiem

${ }_{4}$ Por. F. Mickiewicz, Ewangelia według św. Łukasza, rozdziały 1-11. Wstęp. Przekład z oryginału. Komentarz, cz. 1, Częstochowa 2011, s. 526 (Nowy Komentarz Biblijny).

5 Por. A. Paciorek, Ewangelia według św. Mateusza, rozdziały 1-13. Wstęp. Przekład z oryginatu. Komentarz, cz. 1 poprawiona, Częstochowa 2005, s. 381 (Nowy Komentarz Biblijny).

$6 \quad$ Por. Anonymus, Atlas biblijny, Warszawa 1990, s. 188.

7 Już w mitologii sumeryjskiej pojawiają się wzmianki akcentujące chytrość tego zwierzęcia - za: M. Lurker, Słownik obrazów i symboli biblijnych, tłum. K. Romaniuk, Poznań 1989, s. $116-117$.

8 Stosując tę metaforę do Heroda Antypasa, Jezus niewątpliwie odwołuje się do polityki tetrarchy, którą znamionował wielki spryt, chytra dyplomacja i układy z Rzymem. Zaowocowały one m.in. tym, że Antypas panował nad Galileą i Pereą aż 43 lata (od 4 roku przed Chr. do 39 roku po Chr.) - por. F. Mickiewicz, Ewangelia według św. Łukasza, rozdziały 12-24. Wstęp. Przekład z oryginału. Komentarz, cz. 2, Częstochowa 2012, s. 112-113 (Nowy Komentarz Biblijny). 
to, że lis w porównaniu z wieloma innymi ssakami zamieszkującymi tereny biblijne „buduje” (kopie, wygrzebuje) sobie legowiska, zwane norami i służące mu przede wszystkim do wychowu młodych, a także jako schronienie podczas panowania niekorzystnych warunków atmosferycznych.

Poczynienie takich obserwacji było możliwe, ponieważ do dzisiaj rodzaj Vulpes jest reprezentowany na terenie Izraela przez kilka gatunków i podgatunków lisa, które cechuje duża zmienność zwłaszcza w odniesieniu do ubarwienia i rozmiarów ciała. Łączy je natomiast tryb życia, a przede wszystkim sposób zdobywania pokarmu i jego rodzaj. Zwierzęta te to drapieżniki z rodziny psowatych (Canidae), żywiące się drobną zwierzyną łowną, gryzoniami czy jaszczurkami. Ważnym składnikiem ich diety są także jaja ptaków, owady i owoce. Żywią się także padliną i resztkami ze śmietników miejskich ${ }^{9}$.

Zaznaczyć należy, że lis rudy (Vulpes vulpes) z pewnością był w czasach historycznych, i jest nadal, gatunkiem powszechnie spotykanym na obszarze Izraela. Literatura przedmiotu odnotowuje na omawianym terenie występowanie następujących podgatunków tego drapieżnego ssaka: Vulpes vulpes flavescens (powszechny w północnym Iranie, Kurdystanie i Iraku), Vulpes vulpes palaestina (spotykany w Libanie i Izraelu, zwłaszcza w pasie równin nadmorskich aż po Beer Shebę na południu), Vulpes vulpes niloticus (żyje w Libii i Egipcie, spotkać go można także na Negevie i półwyspie Synaj) oraz Vulpes vulpes arabica (teren jego bytowania to Irak, Arabia Saudyjska i Jemen; zaś w Izraelu notowany jest w południowej części kraju, na Negevie i w Dolinie Arava). Oprócz lisa rudego żyje tu także lis afgański (Vulpes cana). Gatunek ten występuje na terenach pustynnych ze stromymi klifami i zboczami usianymi głazami oraz charakteryzujących się ubogą wegetacją. W Izraelu jest spotykany po zachodniej stronie Morza Martwego (Ein Gedi) aż po Eliat na południu. Trzecim gatunkiem spotykanym na omawianym obszarze jest z kolei lis piaskowy (Vulpes rueppellii sabaea), bardzo podobny do fenka (Vulpes zerda) i często z nim mylony, choć ten ostatni nie jest odnotowywany w składzie gatun-

9 Por. P. France, An encyclopedia of Bible animals, Tel Aviv 1986, s. 62; Świat zwierząt, red. L. Korbel, Warszawa 1989, s. 304; Encyklopedia zwierząt. Ssaki, red. A. Pressley, tłum. E. Świątkowska, P. Świątkowski, Warszawa 1991, s. 20, 136-137. 
kowym fauny Izraela. Lis piaskowy występuje na skalistych i piaszczystych terenach pustynnych od Maroka do Afganistanu, a w Izraelu spotkać go można zwłaszcza w okolicach Morza Martwego i w Dolinie Arava. Charakteryzują go duże uszy, które służą do termoregulacji i lokalizacji zdobyczy oraz futro w kolorze jasnopiaskowym z ciemnymi plamami na pysku i białym końcem ogona. Wszystkie te cechy stanowią wyraźne przystosowanie do środowiska, w jakim to zwierzę żyje. Przed spiekotą dnia chroni się w wykopanej przez siebie norze, która często ma kilka wyjść i jest głębsza niż u wcześniej wymienionych gatunków lisów ${ }^{10}$.

W związku z powyższym rodzi się uzasadniona wątpliwość odnośnie do zoologicznej poprawność stwierdzeń niektórych badaczy, którzy wymieniają fenka jako gatunek przywoływany w analizowanej perykopie (Mt 8, 20; por. Łk 9, 58) ${ }^{11}$. Należy jednocześnie dodać, że sposób życia tego gatunku lisa mocno koresponduje z przyrodniczym tłem i przesłaniem wypowiedzi Mistrza z Nazaretu, bo nadaje mu swoistej plastyczności. Jednak znajomość naturalnego zasięgu występowania fenka wyraźnie wyklucza go spośród zwierząt, które żyły w Izraelu w czasach Jezusa. Jest on bowiem małym liskiem (do $40 \mathrm{~cm}$ długości), zamieszkującym suche i pustynne tereny północnej Afryki i Półwyspu Arabskiego. Fenek to najmniejszy przedstawiciel rodziny psowatych, a zarazem największe zwierzę drapieżne Sahary. Prowadzi nocny tryb życia, natomiast dzień spędza w głębokich, podziemnych norach. Nora fenka, wykopana w zwartej glebie, może mieć nawet $120 \mathrm{~m}^{2}$ i 15 wejść. Gdy grunt jest mniej zwięzły, nory są mniejsze i mają zwykle jedno wejście. Zamieszkiwane są one przez grupy rodzinne ${ }^{12}$.

Przejdźmy teraz do biblijnych „ptaków powietrznych” (syn. „niebieskich”). Wyróżnienie takiej grupy zwierząt jest charakterystyczne dla języka biblijnego. Współcześnie, nawet w mowie potocznej, nie czynimy rozróżnienia na ptaki powietrzne i lądowe. Natomiast wyrażenie „niebieski ptak” przywołujemy, chcąc scharakteryzować człowieka lekkomyślne-

\footnotetext{
10 Por. W. W. Ferguson, The mammals of Israel, Jerusalem 2002, s. 75-77.

11 Tezę taką znajdujemy m.in. w opracowaniu: G. Cansdale, Animals of Bible lands, SydneyToronto-Auckland-Cape Town 1970, s. 124-125.

12 Por. Leksykon zwierząt od A do Ż, red. B. Zasieczna, Warszawa 1992, s. 209-210.
} 
go, nieodpowiedzialnego, próżniaka, darmozjada ${ }^{13}$. Sądzić jednak można, że w czasach Jezusa nie zyskało ono jeszcze przypisywanego mu dzisiaj negatywnego nacechowania, gdyż przywołane wyżej określenia zasadniczo służą autorom biblijnym do pokazania, iż typowym miejscem bytowania dla większości gatunków zaliczanych do tej grupy zwierząt jest przestrzeń powietrzna (por. $\mathrm{Rdz} 7,14$ ), natomiast wysoko położone konary drzew i miejsca odosobnione są miejscem ich gniazdowania. Ponieważ w czasach Jezusa i jeszcze długo po Nim sfera ta była niedostępna dla człowieka, sposób życia ptaków budził u ludzi podziw. W związku z tym nie należy być zaskoczonym, że autor Księgi Amosa zadaje następujące pytanie: „Czy znajdzie się ptak na ziemi, jeśli go nikt nie schwyci?” (Am 3, 5).

Spróbujmy zatem znaleźć odpowiedź na następującą kwestię: co mogło leżeć u podstaw stosunkowo licznych wzmianek o ptakach na kartach Biblii? W pierwszej kolejności należy stwierdzić, że zwierzęta te reprezentowane są na tym stosunkowo niewielkim obszarze, prawie 12 razy mniejszym od powierzchni Polski, przez ok. 500 gatunków należących do gromady Aves. Dla porównania w Stanach Zjednoczonych jest ich tylko o 150 gatunków ptaków więcej. Uwarunkowane jest to nie tylko położeniem geograficznym i zróżnicowanym klimatem omawianego terenu, ale przede wszystkim wynikającą z nich dużą rozmaitością krajobrazów i środowisk. Co więcej tereny te znajdują się na trasie corocznej migracji ptaków (ok. 250 gatunków), które jesienią opuszczają wschodnią i środkową Europę oraz zachodnią Azję, udając się na zimowiska w Afryce. Natomiast wraz z nadejściem wiosny wyruszają w drogę powrotną, pokonując tę samą trasę. Z badań ornitologów wiemy także, że w Izraelu dobre warunki do odpoczynku znajdują zwłaszcza małe ptaki śpiewające przed lub po przekroczeniu Sahary. Natomiast syryjski rów tektoniczny stanowi trasę przelotu ptaków szybujących, np. bocianów, co jest związane z występowaniem nad tym terenem wznoszących prądów powietrza. Wszystko to sprawia, że Izrael uchodzi za jedno z najlepszych miejsc na świecie, gdzie można obserwować migrację ptaków. Wzmiankę o tym zjawisku znajdujemy także w Piśmie Świętym, gdzie czytamy: „Nawet bocian w prze-

13 Por. Wielki słownik frazeologiczny PWN z przysłowiami, red. A. Kłosińska, E. Sobol, A. Stankiewicz, Warszawa 2005, s. 427. 
stworzach zna swoją porę, synogarlica, jaskółka i żuraw zachowują czas swego przylotu. Naród mój jednak nie zna Prawa Pańskiego" (Jr 8, 7) ${ }^{14}$.

Starożytnych fascynował nie tylko fakt opanowania przez nie przestrzeni powietrznej, ale także ich sposób zdobywania pokarmu. Widzieli w nich Boże stworzenia (por. $\operatorname{Rdz} 1,21-22$ ) otoczone jego szczególną troską (por Ps 147, 9), a poprzez to wzór ufności. Do takiej symboliki ptaków nawiązuje w jednej ze swych wypowiedzi Jezus, który mówi: „Przypatrzcie się ptakom w powietrzu: nie sieją ani żną i nie zbierają do spichrzów, a Ojciec wasz niebieski je żywi. Czyż wy nie jesteście ważniejsi niż one?" (Mt 6,26). Natomiast paralelny tekst w Ewangelii według św. Łukasza $(12,24)$, mówiąc o Jezusowym przykładzie opatrznościowej opieki Bożej, przywołuje konkretny gatunek ptaka - jest nim kruk. Co więcej, stanowi to wyraźne nawiązanie do następujących słów przywołanych w Psalmie 147, 9: „On daje pokarm bydłu, pisklętom kruka to, o co wołają".

Podsumowując tę część niniejszego opracowania, warto podkreślić, że lisy i ptaki przywoływane są przez Jezusa w celu skonfrontowania Jego swoistej bezdomności z posiadaniem przez nie „domów”, czyli nor i gniazd. Nie tylko jest to przykład czerpania przez Mistrza z Nazaretu z motywów przyrodniczych, ale też potwierdzenie wnikliwego zmysłu obserwacji, jaki cechował starożytnych. Zestawienie tych zwierząt nie jest zatem przypadkowe, bo w porównaniu z wieloma innymi przedstawicielami świata fauny cechuje je posiadanie własnej nory lub gniazda, służących za schronienie oraz miejsce wychowania młodych.

Informacje te nie tylko stanowią specyficzne tło analizowanej wypowiedzi Chrystusa, ale przede wszystkim uwypuklają jej przesłanie, które sprowadza się do stwierdzenia, że nawet przedstawiciele świata zwierząt są bogatsi od Niego, bo mają miejsca schronienia. Jednakże całe to ubóstwo jest Jego wyborem, a nie dopustem. Powodem tej wybranej przez Jezusa bezdomności jest bycie w drodze i przepowiadanie królestwa Bożego. W ten sposób Mistrz z Nazaretu pokazuje, że naprawdę żyje słowem, które głosi: „Błogosławieni ubodzy w duchu, albowiem do nich należy królestwo niebieskie" (Mt 5, 3; por. Łk 6, 20) i ukazuje właściwy sposób

\footnotetext{
14 Por. U. Paz, Y. Eshbol, Birds in the land of the Bible, Herzila [b.r.w.], s. 6-7.
} 
rozumienia ubóstwa. Nie wybiera on ubóstwa samego w sobie, ale stanowi ono dla niego narzędzie - sposób, aby nas ubogacić (por. 2 Kor 8, 9). Bóg w swej niepojętej logice miłości do człowieka sprawił, że zbawienie nie zostało nam ofiarowane niczym jałmużna bogatego filantropa, dzielącego się tym, co ma ponad stan, ale za przyczyną odwiecznego Syna Bożego, mocą i chwałą równego Ojcu, który z miłości do nas stał się ubogi aż po bezdomność.

\section{Mól w Jezusowym nauczaniu o ułudzie bogactwa}

Ewangeliści - Mateusz i Łukasz - przywołują słowa Jezusa, który poprzez obraz mola, siejącego spustoszenie w skarbcach i magazynach, ukazuje ułudę bogactwa i wszelkiej ziemskiej majętności, a zwłaszcza ich nietrwałość i przemijalność. Pierwszy z wymienionych autorów zapisał: „Nie gromadźcie sobie skarbów na ziemi, gdzie mól i rdza niszczą i gdzie złodzieje włamują się, i kradną. Gromadźcie sobie skarby w niebie, gdzie ani mól, ani rdza nie niszczą i gdzie złodzieje nie włamują się, i nie kradną" (Mt 6, 19-20). Natomiast paralelny tekst w Ewangelii według św. Łukasza brzmi: „Sprzedajcie wasze mienie i dajcie jałmużnę! Sprawcie sobie trzosy, które nie niszczeją, skarb niewyczerpany w niebie, gdzie złodziej się nie dostaje ani mól nie niszczy" (Łk 12,33).

Przywołany w powyższych cytatach mól należy do najliczniejszej gromady w świecie zwierząt, a mianowicie do owadów (Insecta). Co więcej jest jedynym przedstawicielem rzędu motyle (Lepidoptera) wzmiankowanym w Biblii. Zaznaczyć trzeba również, że odniesienia do niego znaleźć można zarówno w Starym, jak i Nowym Testamencie. Autorzy biblijni odwołują się do typowych dla tego gatunku zachowań, zwłaszcza sposobu żerowania (por. Iz 50, 9; 51, 8; Jk 5, 2), i na bazie tego obrazu przenoszą myśl odbiorcy na inną płaszczyznę - pouczenia, najczęściej o kruchości ludzkiej kondycji (por. Hi 13, 28; Ps 39, 12). Perykopy biblijne czynią z mola nie tylko symbol przemijalności, ale także zniszczenia (por. Oz 5, 12; Iż 51, 8).

Jest tak, ponieważ od starożytności mole stanowią poważne zagrożenie dla różnego rodzaju dóbr gromadzonych przez człowieka, zwłaszcza odzieży i przechowywanych w magazynach produktów spożywczych. Do 
najbardziej uciążliwych gatunków, które niewątpliwie były znane autorom biblijnym, należy: mól włosienniczek, zwany też odzieżowym (Tinea biseliella), mól kożusznik (syn. futrzany) (Tinea pellionella) oraz mól ziarniak (Tinea granella). Ponieważ autorzy natchnieni odwołują się do konkretnych spostrzeżeń związanych z życiem tych motyli, warto najpierw zapoznać się z ich biologią. Ważne jest to także z tego powodu, iż niektóre opracowania z zakresu biblistyki, które obecnie podejmują tę tematykę, nie zawsze prezentują poprawny opis entomologiczny w odniesieniu do tego owada ${ }^{15}$.

Dorosłe samce i samice moli żyją ok. miesiąca, nie pobierają pokarmu, tylko korzystają z zapasów zgromadzonych przez larwy, zwane też gąsienicami. Podkreślić trzeba, że właśnie te ostatnie wyrządzają szkody wzmiankowane przez autorów natchnionych. Mole włosienniczek i kożusznik uszkadzają i niszczą przechowywaną odzież, powodując znaczne straty materialne. Natomiast larwy mola ziarniaka żerują na suchych produktach takich jak ziarniaki zbóż, kasze, mąka, suszone owoce itp. ${ }^{16}$.

Mole są drobnymi motylami. Rozpiętość ich skrzydeł wynosi 12-16 mm, a długość ciała od 8 do $12 \mathrm{~mm}$. Latają słabo i niechętnie. Unikają światła, preferując ciemne i zaciszne miejsca. Zaobserwowano, że w przypadku mola włosienniczka lepszymi „lotnikami” są samce. Samice za to dobrze biegają, a nawet skaczą. Odbijają się od podłoża odnóżami trzeciej pary i w powietrzu uderzają 2-3-krotnie skrzydłami, aby wydłużyć skok. Poruszające się w ten sposób samice trudniej jest złapać i zniszczyć niż latające samce ${ }^{17}$.

Samice moli zaraz po zapłodnieniu składają jaja na produktach, które będą pokarmem dla larw. Wylęgające się z nich larwy mają ok. $1 \mathrm{~mm}$.

15 Przykładem są choćby następujące informacje na temat moli, jakie znajdujemy w opracowaniu Słownik tła Biblii, red. J. I. Packer, M. C. Tenney, przekł. Z. Kościuk, Warszawa 2007, s. 195, gdzie czytamy: „Na terenie Izraela występuje kilka odmian tego owada. Wszystkie posiadają dwa stadia rozwojowe. Owad w jednej i drugiej postaci niszczył odzież w czasach biblijnych". W ramach sprostowania należy podkreślić, że powinno się mówić o gatunkach, a nie odmianach tego owada. Jest on motylem, więc przechodzi cztery stadia rozwojowe (jajo, larwa, poczwarka, osobnik dorosły). W przypadku moli zdolność pobierania pokarmu ma tylko stadium larwalne.

16 Por. H. Sandner, Owady. Zwierzęta świata, Warszawa 1989, s. 422.

17 Por. Świat zwierząt, red. H. Grabarczyk, Warszawa 1986, s. 164. 
O ich obecności i intensywności żerowania świadczą białawe oprzędy oraz zanieczyszczenie produktów odchodami. Po właściwym dla danego gatunku czasie, potrzebnym do osiągniecia przez larwy odpowiednich rozmiarów (obejmuje on kilka wylinek), budują one kokon-oprzęd i przepoczwarzają się do postaci dorosłej, czyli uskrzydlonego motyla zdolnego do rozrodu ${ }^{18}$.

Powyższa charakterystyka moli pozwala doprecyzować, o jakich skarbach przez nie niszczonych mówi Jezus. Widzimy zatem, że wyznacznikiem bogactwa na starożytnym Bliskim Wschodzie oprócz złota i srebra były także cenne ubrania i tkaniny. Równocześnie owady te nabierają swoistego znaczenia „opatrznościowego”, bo poprzez swą niszczycielską działalność uświadamiają, co jest prawdziwym bogactwem. Obraz mola ma przede wszystkim uzmysławiać słuchaczom Jezusa, co i gdzie należy gromadzić. Miejscem tym jest „,bank niebieski”, w którym trzeba deponować skarby nieprzemijające. Ulokowanie ich wymaga jednak spełnienia pewnych warunków: wyzbycia się przywiązania do dóbr ziemskich oraz umiejętności dzielenia się nimi, czyli wchodzenia w swoiste bogactwo ubóstwa. Bierze się ono stąd, że wspieranie ubogich jest według Biblii nie tylko filantropią, ale przede wszystkim gestem religijnym, co doskonale wyrażają słowa, jakie Tobiasz (syn) słyszy od swojego ojca: „A wszystkim, którzy postępują sprawiedliwie, dawaj jałmużnę z majętności swojej i niech oko twoje nie będzie skąpe w czynieniu jałmużny! Nie odwracaj twarzy od żadnego biedaka, a nie odwróci się od ciebie oblicze Boga. Jak ci tylko starczy, według twojej zasobności dawaj z niej jałmużnę! Będziesz miał mało - daj mniej, ale nie wzbraniaj się dawać jałmużny nawet z niewielkiej własności! Tak zaskarbisz sobie wielkie dobra na dzień potrzebny, ponieważ jałmużna wybawia od śmierci i nie pozwala wejść do ciemności. Jałmużna bowiem jest wspaniałym darem dla tych, którzy ją dają przed obliczem Najwyższego" (Tb 4, 7-11).

Widzimy zatem, że stanowiące przedmiot naszych rozważań perykopy Mt 6, 19-20 i Łk 12, 33 ukazują sens i istotę ewangelicznego ubóstwa, które ma przede wszystkim prowadzić do ubogacenia wewnętrznego,

18 Por. P. France, An encyclopedia of Bible animals, dz. cyt., s. 108-109; H. Sandner, Owady. Zwierzęta świata, dz.cyt., s. 422. 
czyli ma w nas kształtować postawę duchową, którą cechuje dystans do dóbr materialnych i zawierzenie Bogu.

\section{Lilie polne symbolem bogactwa płynącego z powierzenia się Bożej opiece}

Pośród wypowiedzi Jezusa ukazujących bogactwo ubóstwa znajduje się też taka, która nie tylko wzywa do wspomnianego wyżej ufnego powierzenia się Bożej opiece, ale również w specyficzny sposób nawiązuje do zjawisk zachodzących w świecie flory, a konkretnie do wzrostu i kwitnienia roślin. Autor Ewangelii według św. Mateusza ujmuje to w następujących słowach: „A o odzienie czemu się zbytnio troszczycie? Przypatrzcie się liliom na polu, jak rosną: nie pracują ani przędą. A powiadam wam: nawet Salomon w całym swoim przepychu nie był tak ubrany jak jedna z nich" (Mt 6, 28-29; por. Łk 12, 27). W tym przypadku także warto zastanowić się, dlaczego akurat owe „lilie” zostają przywołane przez Mistrza z Nazaretu, oraz spróbować określić gatunek rośliny, jaki może kryć się pod tym terminem.

Odwołując się zatem do dorobku botaników zajmujących się florą biblijną, przywołane w przytoczonym wyżej cytacie „lilie” można identyfikować z zawilcem wieńcowym (Anemone coronaria L.). Jest on rośliną bulwiastą należącą według obowiązującej dziś systematyki do rodziny jaskrowatych (Ranunculaceae) i powszechnie spotykaną w Ziemi Świętej. Obfitość występowania zawilców zauważalna jest przede wszystkim w porze ich kwitnienia. Jej początek przypada na koniec lutego i początek marca - wtedy pola, zwłaszcza te, na których nie prowadzi się intensywnych zabiegów agrotechnicznych z wykorzystaniem herbicydów, a także zarośla i pustynie, pokrywa kobierzec czerwonych kwiatów ${ }^{19}$. Dodać trzeba, że

19 Kwiaty te osadzone są na łodydze długości $20-40 \mathrm{~cm}$ i mają średnicę 6-8 cm. Trzy wielodzielne i rozmieszczone okółkowo liście podsadki otaczają sześć szkarłatnoczerwonych listków okwiatu, pokrytych od spodu włoskami. Pylniki i nitki pręcików mają u tego gatunku nietypowy dla większości roślin kwitnących czarny kolor. Kwiaty zawilców wieńcowych otwierają się rano i zamykają na noc - za: W. Kawollek, H. Falk, Podróże po biblijnych ogrodach. Informacje o roślinach oraz wskazówki dotyczące ich uprawy, Poznań 2005, s. 118-119. 
właśnie ich barwa jest głównym argumentem przemawiającym za tym, że do kwiatów zawilca wieńcowego porównał Jezus przepych i wspaniałość szat króla Salomona ${ }^{20}$. Związane jest to przede wszystkim z tym, że w starożytności za szczególnie cenne uchodziły materiały i ubrania zafarbowane na kolor purpurowy, szkarłatny, a nawet czerwony. Wiązało się to $z$ ceną barwników używanych do ich wytworzenia ${ }^{21}$.

W związku z powyższym identyfikacja zawilca wieńcowego jako rośliny, do której nawiązuje Jezus w swej wypowiedzi, wydaje się słuszniejsza niż czynienie w tym przypadku odwołań do lilii białej (Lilium candicum L.). Dodać należy, że gatunek ten jest także typowy dla flory Ziemi Świętej. W starożytności był również bardzo ceniony i rozpowszechniony w Egipcie, Asyrii oraz Grecji. Aromatycznych kwiatów lilii używano bowiem do produkcji perfum oraz służyły one za wzór dla detali architektonicznych. Świadectwo na ten temat znajdujemy także w Biblii - dotyczy ono wyglądu głowic kolumn w świątyni jerozolimskiej, którym Salomon kazał nadać kształt tego kwiatu (por. $1 \mathrm{Krl} \mathrm{7,} \mathrm{19.26)}{ }^{22}$.

Dodać również trzeba, że śnieżnobiałe kwity lilii można przyrównać do jednej z cenniejszych tkanin starożytności, a mianowicie bieli produkowanego głównie w Egipcie tzw. „kręconego bisioru”, którego posiadanie było także wyznacznikiem prestiżu i bogactwa. Nosili go bowiem kapłani i ludzie sprawujący ważne urzędy ${ }^{23}$. Nie był on jednak tak cenny jak wspomniane wyżej purpura i szkarłat (por. Ez 27, 16).

\section{Wielbłąd i ucho igielne - Jezusowa hiperbola adresowana do bogaczy}

Innym często przywoływanym cytatem biblijnym, w którym pouczenie na temat bogactwa zobrazowane jest poprzez nawiązanie do świata

20 Por. Z. Włodarczyk, Rośliny biblijne. Leksykon, Kraków 2011, s. 45-46.

${ }^{21}$ Więcej na ten temat: A. M. Wajda, Szkarłat i purpura w Biblii, „Studia Leopoliensia” 5 (2012), s. 123-130.

22 Por. Z. Włodarczyk, Rośliny biblijne. Leksykon, dz. cyt., s. 127-128.

23 Por. B. Szczepanowicz, B. Wesołowska-Kowalska, Moda w Biblii. Odzież, obuwie, nakrycia głowy, fryzury oraz kosmetyki i ozdoby, Kraków 2011, s. 115-116. 
zwierząt, a konkretnie do gatunku o dużym znaczeniu w życiu współczesnych Jezusowi ludzi, są następujące słowa Mistrza z Nazaretu: „Dzieci, jakże trudno wejść do królestwa Bożego tym, którzy w dostatkach pokładają ufność. Łatwiej jest wielbłądowi przejść przez ucho igielne, niż bogatemu wejść do królestwa Bożego" (Mk 10, 24-25; por. Mt 19, 24; Łk 18, 25). $\mathrm{Z}$ dużym prawdopodobieństwem można stwierdzić, że chodzi tu o wielbłąda jednogarbnego (Camelus dromedarius).

Wykorzystanie wielbłąda jako zwierzęcia jucznego na terenie Ziemi Świętej upowszechniło się zwłaszcza w okresie od 1,5 do 1 tys. lat przed Chrystusem ${ }^{24}$. Wcześniej namioty i cały dobytek (majątek ruchomy) ładowano na grzbiety osłów oraz mułów. Wielbłąd, jako zwierzę silniejsze i bardziej wytrzymałe na brak wody i pokarmu, umożliwił przemieszczanie się na znacznie większych dystansach. Dzięki niemu zaczęto przemierzać pustynie i nawet z odległymi miastami oraz osadami można było utrzymywać regularną wymianę towarową ${ }^{25}$. Dlatego w czasach Jezusa widywano je, jak przybywały z pustyni do Jerozolimy i innych miast Palestyny obładowane towarem z dalekiej Azji w karawanach kupców. Dodać trzeba, że dźwigały one na sobie ładunki od 150 do ponad $500 \mathrm{~kg}$, pokonując dziennie znaczne dystanse ${ }^{26}$.

Wróćmy jednak do kontekstu analizowanej perykopy. We wszystkich trzech Ewangeliach synoptycznych wypowiedź ta przywoływana jest tuż po opisie sytuacji z bogatym młodzieńcem, który pyta Jezusa, co ma zrobić, aby osiągnąć życie wieczne. Jezus każe mu sprzedać cały majątek, rozdać ubogim i pójść za sobą. Analizowany fragment jest kontynuacją tej kwestii. Jezus, aby zobrazować, jak trudno wejść do królestwa Bożego tym, co opływają w dostatki, używa tu metafory z uchem igielnym i wielbłądem. Pierwsza myśl, jaka rodzi się po usłyszeniu tych słów,

24 Więcej na ten temat: M. Heide, The domestication of the camel: biological, archaeological and inscriptional evidence from Mesopotamia, Egypt, Israel and Arabia, and literary evidence from the Hebrew Bible, „Ugarit-Forschungen, Internationales Jahrbuch für die Altertumskunde SyrienPalästinas" Bd 42 (2010), s. 331-382.

25 Por. A. Chouraqui, Życie codzienne ludzi Biblii, przekł. L. Kossobudzki, Warszawa 1995, s. 26 .

26 Por. H. Daniel-Rops, Życie w Palestynie w czasach Chrystusa, przekł. J. Lasocka, Warszawa 2001, s. 27. 
może być następująca: bogaczowi nie tylko trudno wejść do królestwa, ale jest to wręcz niemożliwe, tak jak niemożliwe jest przejście wielbłąda przez ucho igły o największym możliwym rozmiarze. Czy o to chodzi Nauczycielowi z Nazaretu?

Na zadanie tego pytania pozwala między innymi zszokowanie uczniów spowodowane rygoryzmem wypowiedzi Pana, które wyraża się w następujących słowach tych, którzy zostawili wszystko i poszli za Nim: Któż więc może się zbawić?

Klucz do odpowiedzi na powyższe kwestie zawiera się w wyjaśnieniu, czym jest „ucho igielne”. Opracowania podają, że jest to nazwa małego otworu w murze, pozwalająca wejść do przedsionka miejskiej bramy. Dzięki niemu osoba wjeżdżająca do miasta na wielbłądzie o późnej porze mogła zostawić objuczone zwierzę przed zamkniętą bramą, a sama przejść przez ten otwór, w którym wielbłąd się nie mieścił. Dopiero rano mógł on zostać wprowadzony wraz z ładunkiem do miasta. Niektórzy dodają, iż otwory te były tak wąskie, że nie mógł przez nie przejść nawet nieobciążony wielbłąd bez niebezpieczeństwa zaklinowania się. Inni zaś sugerują, że taki uwolniony od ładunku wielbłąd mógł przez nie przejść jedynie na kolanach ${ }^{27}$. Dodać jednak trzeba, iż dotychczasowe badania nad budowlami bramnymi z czasów Jezusa nie dostarczyły dowodów na to, aby jakieś otwory w murze nazywano uchami igielnymi. Również w sferze hipotez pozostaje istnienie w Jerozolimie w owym czasie bramy zwanej igielną ${ }^{28}$. Jako ciekawostkę warto jednak dodać, że w Hospicjum św. Aleksandra Newskiego, znajdującym się w pobliżu Bazyliki Grobu Świętego w Jerozolimie, można zobaczyć pozostałości budowli bramnej z II (czasy Hadriana) i IV wieku po Chrystusie (czasy Konstantyna Wielkiego), gdzie obok bramy znajduje się tzw. ucho igielne, które umożliwiało przejście przez mur po jej zamknięciu ${ }^{29}$.

Słowa Jezusa próbowano także wyjaśniać na płaszczyźnie pisowni. Stwierdzono bowiem, że w języku greckim kamelos, oznaczające wielbłą-

27 Por. B. Szczepanowicz, A. Mrozek, Atlas zwierząt biblijnych. Miejsce w Biblii i symbolika, Kraków 2007, s. 61.

28 Por. A. Wąsowski, Biblijno-teologiczny wymiar bramy, Kraków 2014, s. 213-215.

${ }_{29}$ Por. T. Jelonek, Hospicjum św. Aleksandra Newskiego, „Ziemia Święta” nr 1 (77) 2014, s. $22-25$. 
da, pod względem pisowni i brzmienia bardzo przypomina słowo kamilos, czyli „sznur”. W związku z tym wypowiedź Jezusa sprowadzałaby się do następującego stwierdzenia: „Еatwiej jest przejść sznurowi przez ucho igielne niż bogaczowi wejść do królestwa Bożego". Nie znajduje to jednak potwierdzenia w manuskryptach, chociaż obraz ten jest bardziej zrozumiały dla ludzi Zachodu ${ }^{30}$.

Zaznaczyć jednak trzeba, iż zestawienie największego zwierzęcia jucznego znanego w Palestynie w czasach Nowego Testamentu z najmniejszym możliwym przedmiotem używanym w życiu codziennym doskonale pasuje do wypowiedzi Jezusa. Co więcej podobne, a może nawet bardziej kontrastowe zestawienie znajdujemy w Talmudzie Babilońskim, w traktacie Berakot 55b, gdzie żydowska literatura rabiniczna przywołuje motyw słonia przechodzącego przez ucho igielne ${ }^{31}$.

W związku z powyższym należy uznać analizowaną wypowiedź Jezusa za hiperbolę, służącą do pokazania mocy łaski Bożej. Jej przesłanie sprowadza się bowiem do tego, że choćby z ludzkiego punktu widzenia wejście do królestwa Bożego przez bogacza było niemożliwe, to z punktu widzenia Boga nie ma rzeczy niemożliwych i nawet dla osób pokładających ufność $\mathrm{w}$ dobrach doczesnych jest szansa na zbawienie. Bogacz musi jednak najpierw zmienić swoje serce i wyrzec się przywiązania do nich.

Podsumowując, należy stwierdzić, że obrazy ze świata przyrody stanowią istotne tworzywo w nauczaniu Jezusa o ubóstwie i bogactwie. Natomiast wyjaśnienie ich na płaszczyźnie przyrodniczej nie tylko oddaje właściwe tło tych wypowiedzi, ale także stanowi cenny przyczynek do ich egzegezy.

\footnotetext{
30 Por. F. Mickiewicz, Ewangelia według św. Łukasza, rozdziały 12-24..., dz. cyt., s. 280-281.

31 Por. Trudne fragmenty Biblii, red W. C. Kaiser Jr. i in., tłum. L. Bigaj, Warszawa 2011, s. $370-372$.
} 


\section{Summary}

\section{Obrazy ze świata przyrody w nauczaniu Jezusa o ubóstwie i bogactwie}

Obecność licznych przedstawicieli świata zwierząt i roślin na kartach Nowego Testamentu, często połączona z opisem cech charakterystycznych dla ich wyglądu lub sposobu życia czy wykorzystania ich przez człowieka, związana jest z posługiwaniem się przez Jezusa językiem obrazu. Równocześnie należy podkreślić, że ten bogaty świat przyrody jest dla Mistrza z Nazaretu narzędziem pomocnym w przekładaniu orędzia Boga na język ludzki. Dlatego poznanie znaczenia i symboliki zwierząt i roślin pojawiających się na kartach Pisma Świętego pozwala współczesnemu człowiekowi lepiej zrozumieć perykopy biblijne, w których są one przywoływane. W Nowym Testamencie występują opisy, w których Chrystus dla zilustrowania swojej nauki o ubóstwie i bogactwie nawiązuje do życia zwierząt. Przykładem tego są słowa Jezusa: „Lisy mają nory i ptaki powietrzne - gniazda, lecz Syn Człowieczy nie ma miejsca, gdzie by głowę mógł oprzeć” (Mt 8,20). W swym nauczaniu na ten temat Jezus odwołuje się także do ptaków: „Przypatrzcie się ptakom w powietrzu: nie sieją, nie żną i nie zbierają do spichlerzy, a Ojciec wasz niebieski je żywi” (Mt 6, 26). Powyższe słowa świadczą o tym, że słuchacze Jezusa dobrze musieli znać te stworzenia, a zwłaszcza sposób zdobywania pokarmu oraz gnieżdżenia się. Natomiast Jezusowe odniesienie do mola ubraniowego podkreśla znikomość ziemskich bogactw. Zniszczenie ubrań przez mole na terenach biblijnych nie było sporadyczne, ale było czymś, co, biorąc pod uwagę czas, musiało się stać, jak zapisano w słowach Chrystusa: „Nie gromadźcie sobie skarbów na ziemi, gdzie mól i rdza niszczą i gdzie złodzieje włamują się, i kradną" (Mt 6, 19 i Łk 12, 33).

Słowa kluczowe: ubóstwo, bogactwo, Jezus, fauna, flora

Images from the natural world in the teaching of Jesus about poverty and wealth

The presence of numerous animals and plants' names in the New Testament, often accompanied by descriptions of their characteristics, is caused by the fact that the Jesus often used the language of imagery to present the revealed truths to their contemporary listeners. At the same time, it is essential to emphasize the fact that this rich natural world is for the Master of Nazareth just a tool used to translate God's address into human language. For this reason, the knowledge of the animal symbolism in the Holy Writ allows for the accurate understanding of the pericope. In the New Testament we can also come across descriptions in which Christ refers to animal lives in order to illustrate his teachings about poverty and wealth. The following words of Jesus can serve as an example: "Foxes have dens and birds of the sky have nests, but the Son of Man has nowhere to rest his head" (Mt 8:20). Jesus 
also reached for bird images in his teachings about these issues: "Look at the birds in the sky; they do not sow or reap, they gather nothing into barns, yet your heavenly Father feeds them" (Mt 6:26).These words clearly show that those who listened to Jesus had to be familiar with those animals, especially with the way they fed and built their nests. The Jesus description of clothes moths shows the insignificance of earthly riches. The destruction of clothes by the moth in the Bible lands was not an occasional or incidental occurrence, but something which, in the given time, was bound to happen. As recorded in the words of Christ: "Lay not up for yourselves treasures upon earth, where moth and rust doth corrupt, and where thieves break through and steal" (Mt 6:19 and Lu 12:33).

Keywords: poverty, wealth, Jesus, fauna, flora

\section{Bibliografia}

Anonymus, Atlas biblijny, Warszawa 1990.

Cansdale G., Animals of Bible lands, Sydney-Toronto-Auckland-Cape Town 1970.

Chouraqui A., Życie codzienne ludzi Biblii, przekł. L. Kossobudzki, Warszawa 1995.

Daniel-Rops H., Życie w Palestynie w czasach Chrystusa, przekł. J. Lasocka, Warszawa 2001.

Encyklopedia zwierząt. Ssaki, red. A. Pressley, tłum. E. Świątkowska, P. Świątkowski, Warszawa 1991.

Ferguson W.W., The mammals of Israel, Jerusalem 2002.

France P., An encyclopedia of Bible animals, Tel Aviv 1986.

Heide M., The domestication of the camel: biological, archaeological and inscriptional evidence from Mesopotamia, Egypt, Israel and Arabia, and literary evidence from the Hebrew Bible, ,Ugarit-Forschungen, Internationales Jahrbuch für die Altertumskunde Syrien-Palästinas", Bd 42 (2010), s. 331-382.

Jelonek T, Hospicjum św. Aleksandranewskiego, „Ziemia Święta”, nr 1(77) 2014, s. 22-25.

Kawollek W., Falk H., Podróż po biblijnych ogrodach. Informacje o roślinach oraz wskazówki dotyczące ich uprawy, tłum. K. Kwiecień, Poznań 2005.

Kudasiewicz J., Jezus historii a Chrystus wiary, Lublin 1987.

Leksykon zwierząt od A do Ż, red. B. Zasieczna, Warszawa 1992.

Lurker M., Słownik obrazów i symboli biblijnych, tłum. K. Romaniuk, Poznań 1989.

Mickiewicz F., Ewangelia według św. Łukasza, rozdziały 1-11. Wstęp. Przekład z oryginału. Komentarz, cz. 1, Częstochowa 2011 (Nowy Komentarz Biblijny).

Mickiewicz F., Ewangelia według św. Łukasza, rozdziały 12-24. Wstęp. Przekład z oryginału. Komentarz, cz. 2, Częstochowa 2012 (Nowy Komentarz Biblijny).

Paciorek A., Ewangelia według św. Mateusza, rozdziały 1-13. Wstęp. Przekład z oryginału. Komentarz, cz. 1 poprawiona, Częstochowa 2005 (Nowy Komentarz Biblijny).

Paz U., Eshbol Y., Birds in the land of the Bible, Herzila [b.r.w.].

Pismo Święte Starego i Nowego Testamentu w przekładzie z języków oryginalnych, opracował Zespół Biblistów Polskich z inicjatywy Benedyktynów Tynieckich, Poznań 2000. 
Sandner H., Owady. Zwierzęta świata, Warszawa 1989.

Słownik tła Biblii, red. J. I. Packer, M. C. Tenney, przekł. Z. Kościuk, Warszawa 2007. Szczepanowicz B., Mrozek A., Atlas zwierząt biblijnych. Miejsce w Biblii i symbolika, Kraków 2007.

Szczepanowicz B., Wesołowska-Kowalska B., Moda w Biblii. Odzież, obuwie, nakrycia głowy, fryzury oraz kosmetyki i ozdoby, Kraków 2011.

Świat zwierzat, red. H. Grabarczyk, Warszawa 1986.

Świat zwierząt, red. L. Korbel, Warszawa 1989.

Trudne fragmenty Biblii, red. Kaiser W.C. Jr i in., tłum. L. Bigaj, Warszawa 2011.

Wajda A. M., Szkarłat i purpura w Biblii, „Studia Leopoliensia” 5 (2012), s. 123-130.

Wąsowski A., Biblijno-teologiczny wymiar bramy, Kraków 2014.

Wielki słownik frazeologiczny PWN z przysłowiami, red. A. Kłosińska, E. Sobol, A. Stankiewicz, Warszawa 2005.

Włodarczyk Z., Rośliny biblijne. Leksykon, Kraków 2011. 